\title{
$\mathrm{Cu}-\mathrm{Si}$ 삽입금속을 이용한 $\mathrm{DP}$ 강의 $\mathrm{MIG}$ 아크 브레이징 접합부의 미세조직과 기계적 성질
}

\author{
조욱제 ${ }^{*} \cdot$ 윤태진 ${ }^{* *}{ }^{\dagger} \cdot$ 곽승윤 $^{* * *} \cdot$ 이재형*** - 강정윤 ${ }^{* *,+}$ \\ *현대머티리얼 환경사업팀 \\ **부산대학교 소재기술연구소 \\ ****부산대학교 재료공학과
}

\section{Microstructure and Mechanical Properties of Gas Metal Arc Brazed Joint of DP Steel with Cu-Si Filler Metal}

\author{
Wook-Je Cho*, Tae-Jin Yoon**, ${ }^{*}$, Sung-Yun Kwak***, Jae-Hyeong Lee*** \\ and Chung-Yun Kang***, $\dagger$ \\ *Hyundai materials, business environment team, Ulsan 44781, Korea \\ **Institute of materials technology, Pusan National University, Busan 46241, Korea \\ ***Dept. of Material Science and Engineering, Pusan National University, Busan 46241, Korea
}

†Corresponding author : kangcy@pusan.ac.kr, tjyoon@pusan.ac.kr

(Received September 27, 2016 ; Revised October 20, 2016 ; Accepted October 25, 2016)

\begin{abstract}
In this study, Microstructure and tensile properties in arc brazed joints of $1000 \mathrm{MPa}$ grade DP steel using $\mathrm{Cu}-\mathrm{Si}$ insert metal were investigated. The fusion zone was composed of $\mathrm{Cu}$ phase which solidified a little $\mathrm{Fe}$ and $\mathrm{Si}$. The former phase formed due to dilute the edge of base material by arc, although Fe was not solid solution in $\mathrm{Cu}$ at the room temperature. Cu3Si particles formed by crystallization at $1100^{\circ} \mathrm{Cduring}$ faster cooling. After the tensile shear test, there are no differences between the brazed joint efficiencies.

The maximum joint efficient was about $37 \%$ compared to strength of base metal. It is better than that of arc brazed joint of DP steel using $\mathrm{Cu}-\mathrm{Sn}$ filler metal. Fracture position of all brazing conditions was in the fusion zone. Crack initiation occurred at three junction point which was a stress singularity point of upper sheet, lower sheet and the fusion zone. And then crack propagated across the fusion zone. The reason why the fracture occurred at fusion zone was that the hardness of fusion zone was lower than that of base material and heat affected zone. The correlation among maximum load and hardness of fusion zone and EST at fractured position was $\mathrm{R}^{2}=0.9338$. Therefore, this means that hardness and EST can have great impact on maximum load.
\end{abstract}

Key Words : DP steel, Gas metal arc brazing, Cu-Si filler metal, Microstructure, Tensile shear test

1. 서 론

Dual phase(이하 DP) 강은 마르텐사이트와 페라이 트의 2상 조직으로 구성되어 있으며, 1980년대에 개발 되어 유럽에서 자동차 산업에 적극적으로 적용되기 시 작하였다. 국내에서도 자동차 차체의 트렁크리드(Trunk $\mathrm{lid}$, 사이드 필러 등에 주로 적용이 되고 있다 ${ }^{1,2)}$. 이 러한 부분은 특히 외부에 노출되는 부분이기 때문에 미 려한 용접, 접합부가 요구되고 있는 것이 특징이다. $\mathrm{DP}$ 강을 비롯한 첨단고장력강판에 Gas metal arc welding(이하, GMAW), Gas tungsten arc welding(이 하, GTAW)과 레이저 용접 (Laser welding) 등의 용 융 용접을 적용할 경우, 용접 시 과도한 입열로 인하여 
모재가 심하게 변형되거나, 기공, 스패터 등과 같은 결 함이 발생하여 용접부가 미려하지 않은 문제점이 발생 한다 ${ }^{3-5)}$.

한편 아크 브레이징은 GMA 또는 GTA 용접장치를 이용하여 삽입금속과 모재사이에 아크를 발생시킨다. 발생된 아크는 삽입금속을 먼저 녹이고, 용융된 삽입금 속은 접합부에서 모세관 현상에 의하여 흐르게 되어 모 재의 용융이 거의 없이 모재를 접합하는 공정이다. ${ }^{6)}$ 이 공정의 장점은 강판에 대한 열영향이 적고, 자동화가 용 이하며, 또한 역극성 전원을 사용함에 따라 모재의 청 정작용으로 플럭스 사용이 불필요하고, 스패터 또는 흄 의 발생이 아주 적다는 장점을 가지고 있다 ${ }^{7,8)}$.

아크 브레이징에 관한 연구는 주로 Galvanized Transformation Induced Plasticity(TRIP)강, Galvanized $\mathrm{DP}$ 강, Bare $\mathrm{DP}$ 강에 적용한 연구가 활발히 진행되고 있다. 특히 $\mathrm{DP}$ 강에 아크 브레이징을 적용한 연구를 살 펴보면, Rangel 등은 Galvanized 강에 아크 브레이 징을 적용하면 접합 시 낮은 입열에 의하여 $\mathrm{Zn}$ 의 기화 를 방지하여 미려한 접합부를 얻을 수 있다고 보고하였 다. ${ }^{9)}$ 한편 $\mathrm{Cho}$ 등은 $\mathrm{Cu}-\mathrm{Sn}$ 삽입금속을 이용하여 접 합부의 미세조직과 기계적성질에 미치는 브레이징 전류 의 영향을 조사하였다. 브레이징 전류가 증가함에 따라 접합부의 강도가 증가하였으나, 모재 대비 접합효율이 $30 \%$ 미만으로 매우 낮았다 ${ }^{10)}$.

따라서 본 연구에서는 자동차 차체용 인장강도 $1000 \mathrm{MPa}$ 급 $\mathrm{DP}$ 강의 아크 브레이징 기술을 확립 및 기존과 다른 $\mathrm{Cu}-\mathrm{Si}$ 삽입금속을 이용하여, 접합부의 기계적 성질과 미세조직의 변화를 브레이징 전류를 변화하여 검토하였다.

\section{2. 실험방법}

본 실험에서 사용된 소재는 두께가 $1.6 \mathrm{~mm}$ 인 Dual Phase(DP)강이며, 화학조성과 기계적 성질을 Table 1 에 나타낸다. 브레이징 시험편은 200x100 mm 크기 로 미리 가공하였다. 가공된 시편은 아세톤으로 표면 탈지를 한 후 $10 \mathrm{~mm}$ 를 겹쳐서 위치한 후 브레이징을 실시하였다. 브레이징은 $\mathrm{GMAW}$ 자동 용접기를 사용하

Table 1 Chemical composition and mechanical properties of raw materials $(w t \%)$.

\begin{tabular}{|c|c|c|c|c|c|c|c|}
\hline $\mathrm{C}$ & $\mathrm{Mn}$ & $\mathrm{Si}$ & $\mathrm{Mo}$ & $\mathrm{N}$ & $\mathrm{Nb}$ & $\mathrm{Ti}$ & $\mathrm{Fe}$ \\
\hline 0.108 & 3.187 & 0.167 & 0.008 & 0.009 & 0.05 & 0.013 & Bal. \\
\hline
\end{tabular}

\begin{tabular}{|c|c|c|c|}
\hline Hardness(Hv) & Y.S(Mpa) & T.S(Mpa) & El(\%) \\
\hline 340 & 728 & 1040 & 17.65 \\
\hline
\end{tabular}

였고, 이 때 직류전극 플러스 $(\mathrm{DCEP})$ 와 펄스전원을 사 용하였다. 토치는 하판과 $75^{\circ}$ 로 기울인 상태로 진행하 였고, 모재와 전극간의 거리(CTWD)는 $10 \mathrm{~mm}$ 으로 고정하였다. 브레이징 장치에 대한 자세한 그림과 브레 이징 실험조건은 Fig. 1과 Table 1에 각각 나타내었다.

아크 브레이징한 시편의 미세조직은 $2 \%$ 나이탈 $\left(\mathrm{HNO}_{3}\right.$ $2 \mathrm{~m} \ell+\mathrm{C}_{2} \mathrm{H}_{5} \mathrm{OH} 98 \mathrm{~m} \ell$ ) 용액으로 $2 \sim 10$ 초간 부식시켜, 광 학현미경(Optical microscopy, 이하 $\mathrm{OM}$ )과 주사식전 자현미경(Scanning Electron Microscope, 이하 SEM) 으로 관찰하였다.

접합부와 모재의 경도분포는 미소경도시험기를 사용 하여 하중 (load) 은 $300 \mathrm{gf}$, 유지시간은 10 초로 하여 측 정하였다.

인장전단 시험은 박판소재 인장시험 규격인 $\mathrm{ASTM}$ $\mathrm{A} 370$ 을 사용하여 실시하였고, 인장시험 시 크로스헤드 의 속도는 $5 \mathrm{~mm} / \mathrm{min}$ 로 고정하여 실시하였다.

\section{3. 실험결과 및 고찰}

\section{1 원소재의 미세조직}

Fig. 2는 본 연구에 사용된 $\mathrm{DP}$ 강 모재의 미세조직을 나타낸 것이다. Fig. 2(a)는 모재의 광학현미경 조직이 고, Fig. 2(b)는 임이의 영역을 확대한 주사전자현미경 사진이다. 이것으로부터 모재 미세조직은 페라이트 $(\mathrm{F})$,

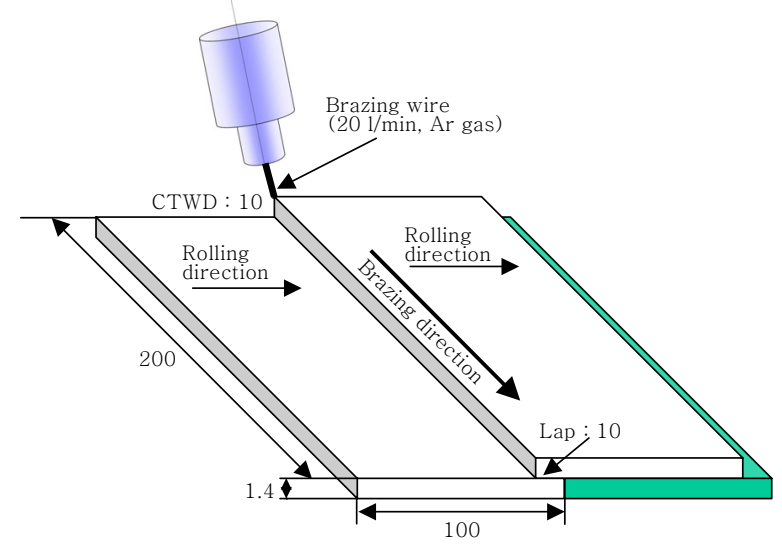

Fig. 1 Illustration for arc brazing process

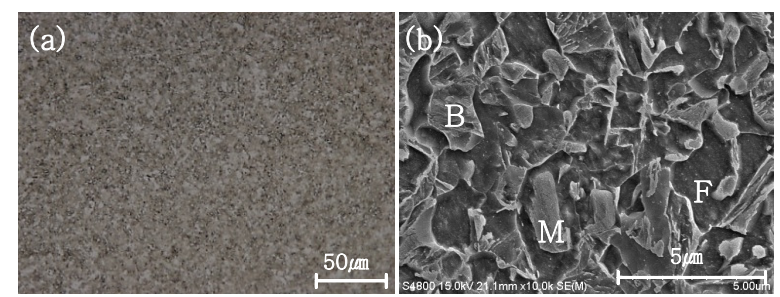

Fig. 2 Microstructure of the base metal 

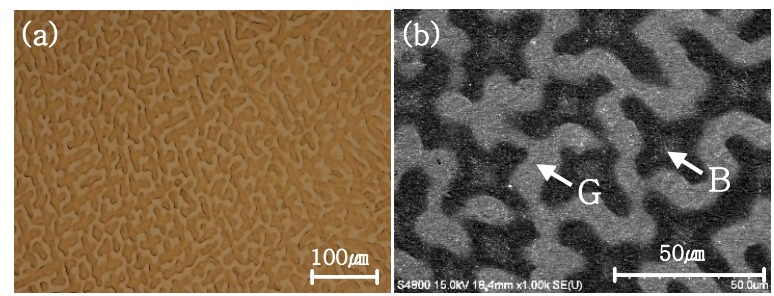

Fig. 3 Microstructure of the filler metal (a) OM image, (b) SEM image

Table 2 EDS results of phases denoted by B and G in (b) in Fig. 3

\begin{tabular}{|c|c|c|c|}
\hline Color & $\mathrm{Cu}$ & $\mathrm{Si}$ & phase \\
\hline Gray & 93.7 & 6.8 & $\mathrm{Cu}$ \\
\hline Black & 93.0 & 18.7 & $\mathrm{Cu}_{33} \mathrm{Si}_{7}$ \\
\hline
\end{tabular}

마르텐사이트(M) 그리고 베이나이트(B) 3 상으로 구 성되어 있음을 알 수 있다.

본 연구에 사용된 $\mathrm{Cu}-\mathrm{Si}$ 삽입금속 와이어의 원래의 응고조직을 관찰하기 위하여 와이어의 적당량을 세라믹 도가니에 넣은 후 고주파 용해로로 응고시켜 미세조직 을 관찰하였다.

Fig. 3은 용해 후 응고된 삽입금속의 광학현미경 사 진(a) 및 $\mathrm{SEM}$ 사진 $(\mathrm{b})$ 을 타나낸 것이다. 이것으로부 터 삽입금속의 응고조직은 회색 상 $(\mathrm{Gray} ; \mathrm{G})$ 과 흑색 상(Black; B)으로 이루어진 전형적인 덴드라이트 조직 을 나타내는 것을 알 수 있다. 회색 $(\mathrm{G})$ 과 흑색 $(\mathrm{B})$ 의 구성원소를 알아보기 위하여 각 영역의 $\mathrm{EDS}$ 점 분석 을 실시하였고, 그 결과를 Table 2에 나타내었다.

이것으로부터 회색상 $(\mathrm{G})$ 은 순수 $\mathrm{Cu}$ 상이고, 흑색상 (B)은 $\mathrm{Cu}-\mathrm{Si}$ 화합물임을 알 수 있다. 이 화합물은 조 성분석 결과와 $\mathrm{Fig}$. 4에 나타낸 $\mathrm{Cu}-\mathrm{Si}$ 2원계 평형상

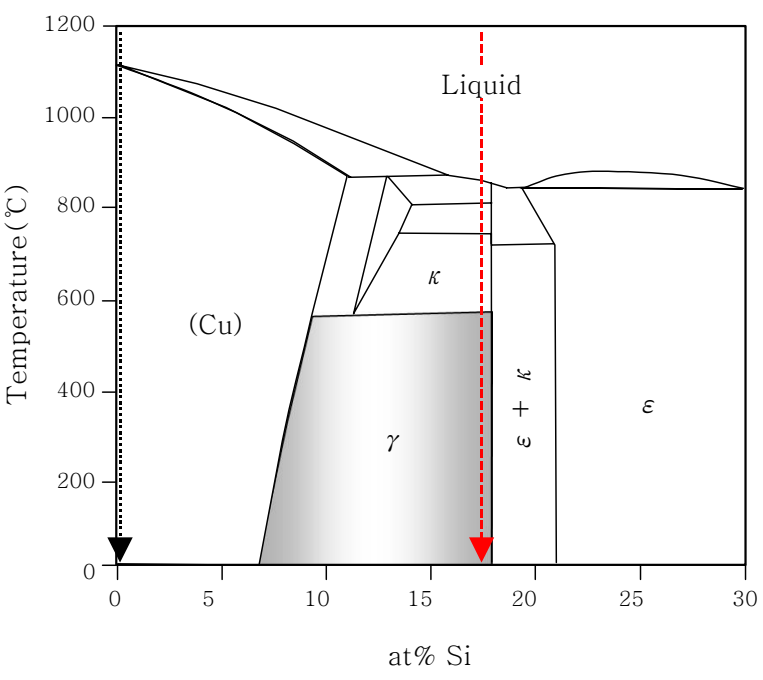

Fig. 4 Binary phase diagrams calculated by thermocalc

태도로부터 8 영역의 $\mathrm{Cu}_{33} \mathrm{Si}_{7}$ 상인 것을 알 수 있다.

\section{2 아크 브레이징부의 비드외관과 미세조직}

Fig. 5는 아크 브레이징한 접합부의 비드 외관의 사 진과 단면 거시조직의 광학현미경 사진을 나타낸 것이 다. Fig. $5(\mathrm{a}-\mathrm{c})$ 의 접합부 표면 사진으로부터, 비드 표 면은 기공, 크랙 등의 표면결함이 없고, 시작부 부터 종 료부 까지 안정한 것을 알 수 있다. Fig. $5(\mathrm{~d}-\mathrm{f})$ 의 단 면사진으로부터, 접합부 단면에서는 삽입금속이 용융, 응고되어 볼록하게 접합부가 형성이 된 전형적인 겹치 기 이음부의 형상인 것을 알 수 있고, 삽입금속의 내부 에 기공, 크랙, 불완전용입 (Incomplete penetration) 과 같은 내부 결함이 없는 것을 알 수 있다.

선행연구 결과에 따르면 겹치기 아크 브레이징 접합 부의 경우, 모재와 삽입금속의 계면에서 생성되는 계면 반응층이 인장성질에 큰 영향을 미치는 중요한 인자로


Fig. 5 Surface bead appearances (a-c) and cross sections (d-f), of brazed with brazing current; (a),(d) 60A, (b),(e) 70A, (c),(f) $80 \mathrm{~A}$ 

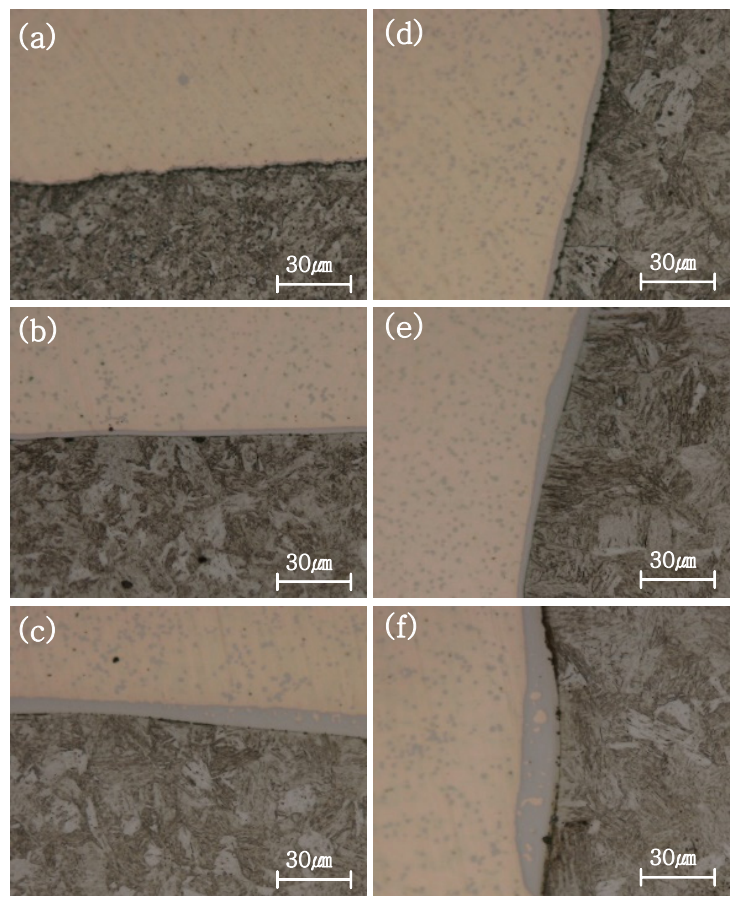

Fig. 6 OM images of bottom joint interface(a-c) and side joint interface(d-f) with brazing current (a),(d) $60 \mathrm{~A},(\mathrm{~b}),(\mathrm{e}) 70 \mathrm{~A}$, (c),(f) $80 \mathrm{~A}$

보고되고 있다 ${ }^{10)}$. 따라서 전류조건에 따른 삽입금속과 모재의 접합 계면부를 자세히 관찰하여 보았다.

Fig. 6은 Fig. 5의 (d-f)의 $\square$ 로 표시한 영역인 삽 입금속과 상판의 접합계면과 하판의 접합계면을 확대한 광학현미경 사진을 나타낸다.

이것으로부터 삽입금속-상판, 하판 간 각각의 접합계 면에 수 um 두께의 회색층 형성되어있는 것을 알 수 있다. 그리고 위치와 전류에 따라 회색 층의 두께 차이 가 약간 있음을 알 수 있다. 이 회색 층을 자세히 알아 보기 위하여 $\mathrm{SEM}$ 을 이용하여 고배율에서 삽입금속과 모재 사이에 형성되는 회색층의 관찰하였고, 그 결과를 Fig. 7에 나타내었다. 이것으로부터 접합부 단면의 미

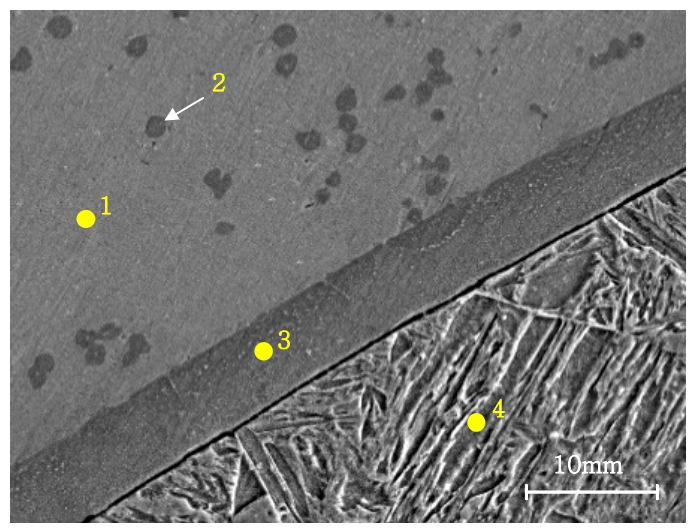

Fig. 7 SEM image marked rectangle area in Fig. 6(e)
Table 3 Point analysis by EDS. (1) Filler metal matrix, (2) particle in brazed zone, (3) joint interface and (4) base metal

\begin{tabular}{|c|c|c|c|c|}
\hline No. & $\mathrm{Cu}$ & $\mathrm{SI}$ & $\mathrm{Fe}$ & $\mathrm{Mn}$ \\
\hline 1 & 90.2 & 4.6 & 5.2 & - \\
\hline 2 & - & 27.2 & 72.8 & - \\
\hline 3 & - & 24.4 & 75.6 & - \\
\hline 4 & - & - & 97.4 & 2.6 \\
\hline
\end{tabular}

세조직은 삽입금속부의 기지조직 (1), 삽입금속내부의 구상조직 (2)삽입금속과 모재 사이에 형성된 띠 층 (3), 그리고 모재 조직 (4)의 4 영역으로 이루어져있는 것 을 알 수 있다. 이 4 영역의 성분분석을 위하여 $\mathrm{EDS}$ 점분석을 실시하였고 그 결과를 Table 3 에 나타낸다. 이것으로부터 삽입금속부의 기지조직은 $\mathrm{Fe}$ 와 $\mathrm{Si}$ 를 다 소 고용하고 있는 $\mathrm{Cu}$ 상이고, 삽입금속내부의 구상조 직은 $\mathrm{Fe}-\mathrm{Si}$ 이며, 삽입금속과 모재 사이에 형성된 띠 층은 구상조직과 동일한 성분을 보이므로 삽입금속부에 생성된 $\mathrm{Fe}-\mathrm{Si}$ 과 같은 상으로 생각된다.

계면반응층의 정확한 분석을 위해서 접합부의 삽입금 속부분만을 도려내어 전해추출을 실시하였고, 삽입금속 부분만을 일부 녹여낸 시편을 $\mathrm{SEM}, \mathrm{EDS}$ 분석을 실시 하였다. Fig. 8(a)는 전해추출 후의 접합시편의 분석위

(a)


Fig. 8 (a) Illustration of specimen by electro extracted, (b) SEM image at interface denoted rectangle area in Fig.8(a), (c) SEM image of poweder after extracted and filtered (d) High magnified SEM image of filtered powder 
치를 나타낸 모식도이고, Fig. 8(b)는 Fig. 8(a)의 $\square$ 로 표시된 영역의 SEM 사진이다. 또한 Fig. 8(c)와 (d) 는 삽입금속부분의 전해추출 한 용액을 메시로 걸러 서 얻어진 잔사의 $\mathrm{SEM}$ 사진을 나타낸 것이다. 이것으 로부터 삽입금속부와 모재부 사이에 수 um두께의 계면 반응층이 존재하고 있음을 알 수 있으며, 삽입금속내부 에서는 다량의 구상이 존재하는 것을 알 수 있다. 구상 의 상동정을 위하여 XRD 분석을 실시하였고, 그 결과 를 Fig. 9에 나타내었다. 이것으로부터 삽입금속과 모 재 사이에 형성된 반응층과 삽입금속내부에서는 다량의 구상은 $\mathrm{Fe}_{3} \mathrm{Si}$ 상인 것을 알 수 있다.

삽입금속부 내의 $\mathrm{Fe}_{3} \mathrm{Si}$ 구형의 형성 기구를 고찰하 기 위하여 열역학적 상태도 시뮬레이션 소프트웨어인 Thermo-Calc. (TCW5)를 사용하여 상태도를 예측하 였고, 그 결과를 Fig. 10에 나타내었다. Fig.10에 나타 낸 상태도의 데이터 입력값은 (Input data) 삽입금속 부의 $\mathrm{EDS}$ 점분석 결과 $(3.83 \mathrm{wt} . \% \mathrm{Fe}, 3.18 \mathrm{wt} \% \mathrm{Si}$, $92.99 \mathrm{wt}, \% \mathrm{Cu}$ )를 이용하였다. 이것으로부터 상태도내 에 화살표로 표시한 $92.99 \mathrm{wt} . \% \mathrm{Cu}$ 에서 $\mathrm{Fe}_{3} \mathrm{Si}$ 상이

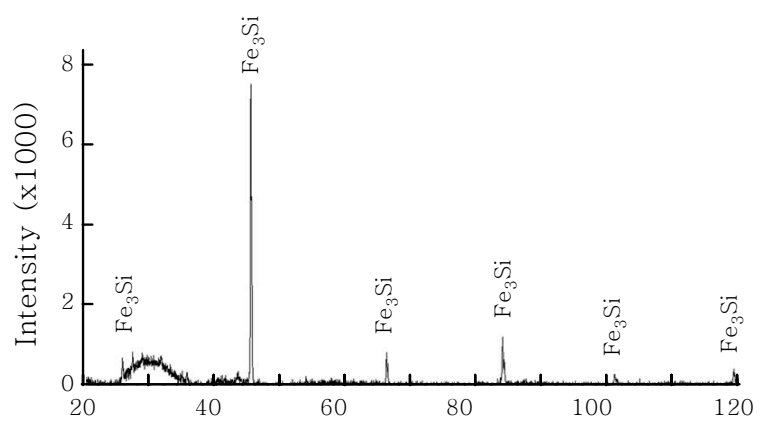

Fig. 9 X-ray diffraction pattern of particle by electro extraction

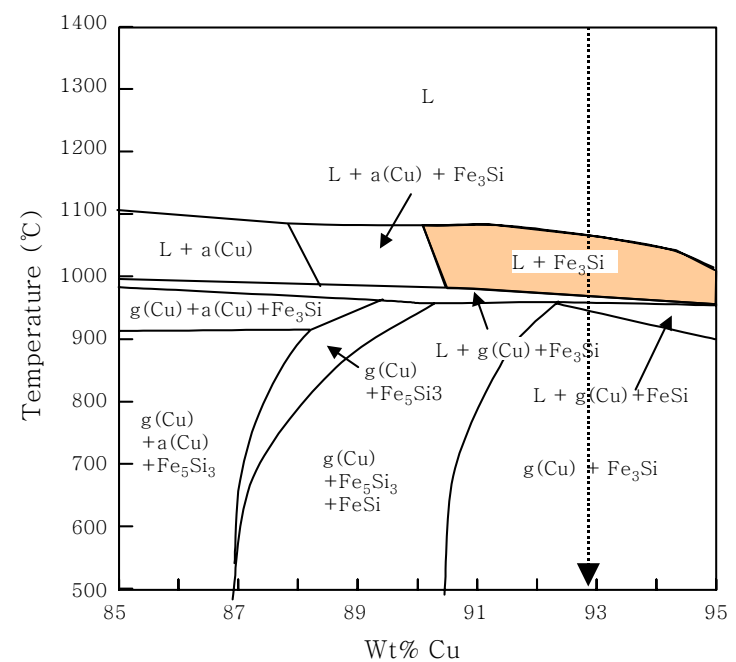

Fig. 10 Binary phase diagrams calculated by thermocalc
생성되는 것을 알 수 있고, 이것은 아크 브레이징 과정 에서 삽입금속과 모재의 일부가 용융되고, 냉각하면서 정 출 (약 $1100^{\circ} \mathrm{C}$ 부근) 되는 것으로 생각된다.

\section{3 기계적 성질}

Fig. 11은 브레이징 전류에 따른 인장하중을 나타낸 것이고, Fig. 12 는 파단된 시편의 단면 $\mathrm{OM}$ 사진을 나

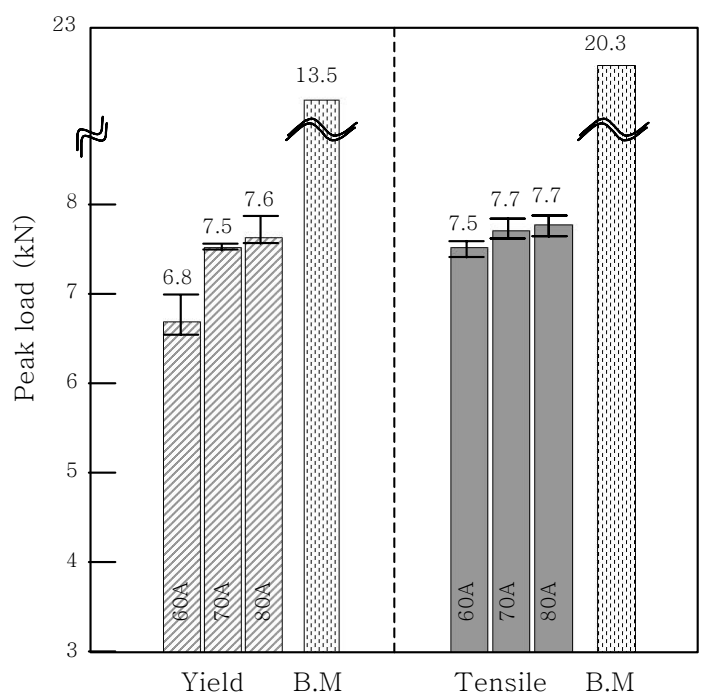

Fig. 11 Tensile and yield properties with brazing currents
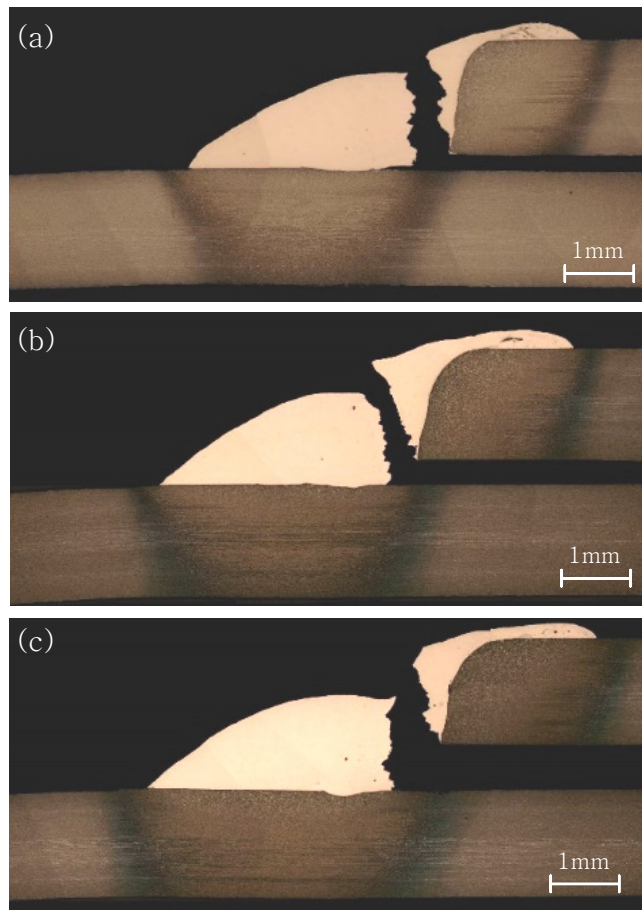

Fig. 12 Cross sections of fractured specimens $((\mathrm{a}) \sim(\mathrm{c}))$ and enlarged micro structures $((\mathrm{d}) \sim(\mathrm{f}))$ of zone denoted by $\square$ in (a) (c). (a), (d) : 60A, (b), (e) : $70 \mathrm{~A},(\mathrm{c}),(\mathrm{f}): 80 \mathrm{~A}$ 
타낸 것이다. 접합시편의 크기로 모재를 인장한 경우, 인 장하중은 약 $20.3 \mathrm{kN}$ 이었다. 인장하중 값은 약 $200 \mathrm{~N}$ 이내로 큰 차이를 보이지 않았으나, 브레이징전류가 증 가함에 따라 약간 증가하는 것을 알 수 있다. 최대 접 합효율은 모재대비 약 $37 \%$ 이었다. 이 때의 파단위치 는 전단응력에 의한 상판과 하판의 모재의 계면에서 일 어나는 계면파단이 아닌 Fig. 12 와 같이 상판과 하판 그 리고 삽입금속이 만나는 3 중점(Three point junction) 에서 파단이 시작되어 삽입금속의 상부로 인장응력에 의 하여 파단이 되었음을 알 수 있다.

모든 파단이 상, 하부판과 삽입금속이 만나는 3 중점에 서 파단되는 이유를 알아보기 위하여 용융부에서 모재 까지 경도분포를 조사하였고, 그 결과를 Fig. 13에 나타 내었다.

한편 선행연구에서 $\mathrm{DP}$ 강에 $\mathrm{Cu}-\mathrm{Sn}$ 삽입금속을 적용 한 아크 브레이징 접합부의 접합효율은 모재대비 약 $30 \%$ 미만으로 아주 낮다고 보고되었는데, 이보다는 접합부 의 강도가 다소 향상된 것을 알 수 있다. 이것으로 부 터 $\mathrm{Cu}-\mathrm{Si}$ 합금 용융부의 경도값 (강도)은 모재인 $\mathrm{DP}$

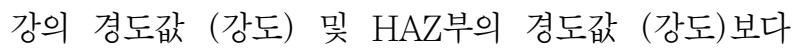
낮기 때문에, 용융부에서 파단이 된 것으로 생각된다.

한편, 전류에 따라 접합부의 인장하중이 차이가 나는 이유를 파악하기 위하여, 파단부 단면을 자세히 검토하 였다. 아크 브레이징 시 접합부에서 파단이 발생하는 경 우, 접합부의 하중은 용융부의 강도와 파단부 유효두께 (Effective Sheet Thickness: EST)에 의하여 결정 된다고 보고되었다 ${ }^{11)}$. 순수 용융부의 강도를 측정하는 것은 불가능하기 때문에, 강도와 비례관계가 있는 ${ }^{12)}$ 용 융부의 경도를 조사하였고, 그것의 평균 경도값을 Fig. 14에 나타내었다. 이것으로부터 전류값이 증가함에 따 라 용융부의 경도가 약간 상승하는 경향이 있는 것을 알 수 있다. 전류값의 증가에 따라 용융부의 경도값이

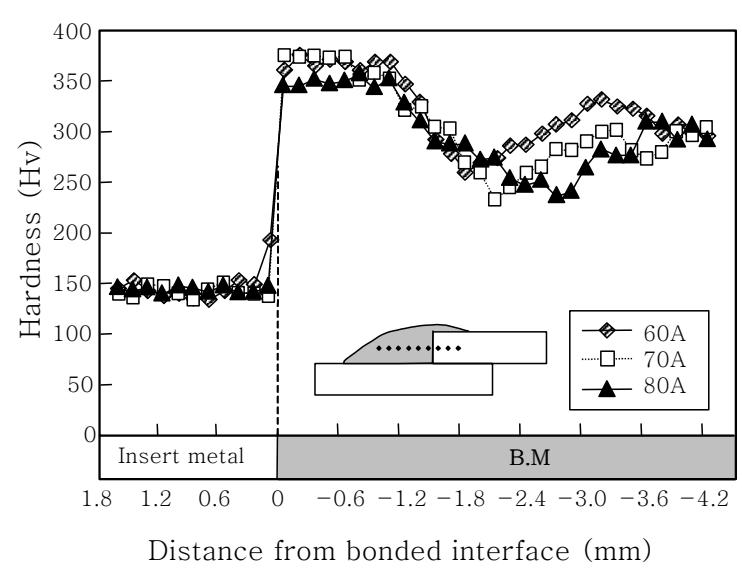

Fig. 13 Hardness distribution of Insert metal matrix with respect to brazing current
상승하는 이유는 Fig. 6에서 언급하였듯이 용용부 내부 의 $\mathrm{Fe}_{3} \mathrm{Si}$ 구상과 관련이 있을 것이라 생각하여 $\mathrm{Fe}_{3} \mathrm{Si}$ 분률(Volue fraction)을 측정한 후 용융부의 경도값과 의 상관관계를 조사하였고, 그 결과를 Fig. 15 에 나타 내었다. 이것으로부터 브레이징 전류값이 증가함에 따 라 용융부 평균 경도값이 커지는 이유는 용융부 내부에 $\mathrm{Fe}_{3} \mathrm{Si}$ 구상의 분율이 증가하기 때문인 것으로 생각된다. 파단부 유효두께는 Fig. 12 에서 나타난 것과 같이 3 중 점에서 파단 종료지점의 두께로 정의하여 측정하였다. 측정한 결과를 이용하여 용융부의 경도값과 파단부 유 효두께에 따른 인장하중과의 상관관계를 확인하기 위하 여 선형 회귀분석(linear regression analysis)을 하 였고, 그 결과를 Fig. 16에 나타내었다. 실험의 독립변 인은 용융부의 경도값과 파단부 유효두께의 측정값이 고, 이에 따른 종속변인은 인장하중값이다. 이 결과로 부터 용융부의 경도값 및 파단부의 유효두께와 인장하 중값의 관계는 매우 높은 선형관계를 나타내었고, 이때 의 상관계수는 0.9338 이었다.



Fig. 14 Variations of average hardness with respect to brazing current

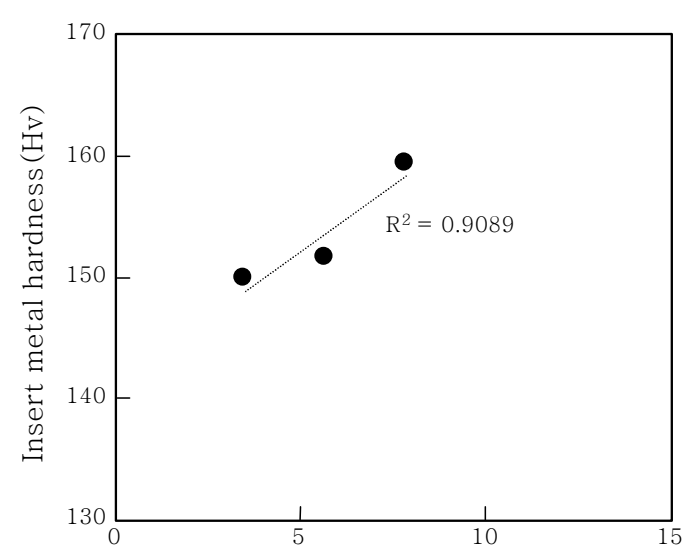

IMC volume fraction(\%)

Fig. 15 Correlation between IMC volume fraction in insert metal matix and hardness 




Fig. 16 Linear regression model with independent variables (EST and hardness) and dependent variable (tensile shear load)

\section{4. 결 론}

$1000 \mathrm{MPa}$ 급 $\mathrm{DP}$ 강에 $\mathrm{Cu}-6.3 \mathrm{wt} \% \mathrm{Si}$ 삽입금속을 적 용한 아크 브레이징 접합부의 미세조직과 기계적 성질 에 대하여 검토한 결과, 다음과 같은 결론을 얻었다.

1) 아크 브레이징 후 접합부의 표면 및 내부에 기공, 크랙, 불완전용입(Incomplete penetration)과 같은 내부 결함이 발생하지 않는 건전한 접합부를 얻었다.

2) 용융부의 기지조직은 $\mathrm{Fe}$ 와 $\mathrm{Si}$ 를 다소 고용하고 있는 $\mathrm{Cu}$ 상이고, 용용부 내부에 파티클 형상의 $\mathrm{Cu}_{3} \mathrm{Si}$ 상으로 구성되어 있었다. $\mathrm{Fe}_{3} \mathrm{Si}$ 상이 용융부에 생성되 는 이유는 아크 브레이징 과정에서 삽입금속과 모재의 일부가 용융되고, 냉각하면서 약 $1100^{\circ} \mathrm{C}$ 부근에서 정출 되기 때문이다.

3) 전단인장 시험 시 피크하중은 모재대비 약 $37 \%$ 이었으며, 브레이징 전류 변화에도 약 $200 \mathrm{~N}$ 이내로 큰 차이를 보이지 않았고, 파단은 상부모재/하부모재/용융 부와 만나는 3 중점에서 최초 크랙이 발생하고, 용융부 내부로 전파되어 인장응력에 의하여 발생하였다.

4) 용융부의 경도(강도)는 모재와 HAZ의 경도값보 다 낮기 때문에 용융부에서 파단이 발생하였고, 피크하 중은 용융부의 경도(강도)와 파단부의 유효두께에 따라 결정되었다.

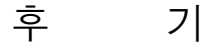

이 논문은 2016년도 정부(미래창조과학부)의 재원으 로 한국연구재단의 지원을 받아 수행된 연구임.

(No. 2012R1A5A1048294).

\section{References}

1. R. KUZIAK, R. KAWALLA, S. WAENGLER, Advanced high strength steels for automotive industry, Archives of Civil and Mechanical Engineering, 8(2), (2008), 103

2. Y. Sakuma, O. Matsumura and H. Takechi, Mechanical properties and retained austenite in intercritically heattreated bainite-transformed, Metallurgical Transactions A, 22(2), (1991), 489

3. S. L. Yang and R. Kovacevic, Welding of Galvanized DualPhase 980 Steel in a Gap-Free Lap Joint Configuration, Welding Journal, 88, (2009), 168

4. Kim, C., Choi, W., Kim, J., and Rhee, S., Relationship between the weldability and the process parameters for laser-TIG hybrid welding of galvanized steel sheets, Materials Transactions 49(1), (2008), 179

5. Gualini, M. M. S., Iqbal, S., and Grassi, F., Modified dual-beam method for welding galvanized steel sheets in lap configuration, Journal of Laser Applications 18(3), (2006) 185

6. The Korean Welding and Joining Society, Weldin Handbook, 3 (2007), 172 (in Korean)

7. C. Chovet, S. Guiheux, Possibilities offered by MIG and TIG brazing of galvanized ultra high strength steels for automotive applications, la metallurgla Itallana, 7, (2006), 47

8. D. Iordachescu, L. Quintino, R. Miranda, G. Pimenta, Influence of shielding gases and process parameters on metal transfer and bead shape in MIG brazed joints of the thin zinc coated steel plates, Materials and Design, 27, (2006), 381

9. A.F. Rangel, L.A. Matlakhova, R.P.D.R. Paranhos, A.N. Malakhov, Evaluation of MIG-brazing welded joint by means of metallographic techniques, Welding International, 20, (2006). 889

10. Wook-Je Cho, Young-Ho Cho, Jung-Gil Yun and ChungYun Kang, Microstructure and Tensile Strength Property of Arc Brazed DP steel using Cu-Sn Insert Metal, Journal of KWJS, 31 (1), (2013), 58 (in Korean)

11. J. R. Cahoon, W. H. Broughton and A. R. Kutzak, The Determination of Yield Strength From Hardness Measurements, Metallurgical transactions, 2 (1970), 1971 